\section{Effect of End-of-production High- energy Radiation on Nutritional Quality of Indoor-grown Red-leaf Lettuce}

\author{
Celina Gómez and Juan Jiménez \\ Environmental Horticulture Department, University of Florida, Gainesville, \\ FL 32611
}

Additional index words. anthocyanin, antioxidants, carotenoids, LED, light quality, nitrate, indoor farm

\begin{abstract}
Numerous studies have evaluated the effect of high-energy radiation as means to increase nutritional quality of lettuce (Lactuca sativa). However, most research has focused on providing constant radiation quality or quantity throughout the production cycle, which typically results in yield reductions or increases in production costs. End-ofproduction (EOP) radiation is a cost-effective, preharvest practice that can allow growers to manipulate product quality and thus increase market value of lettuce without negatively affecting plant growth. The objective of this study was to quantify and compare growth and accumulation of secondary metabolites from 'Rouxaï $R Z$ ' and 'Codex RZ' red-leaf lettuce grown indoors and exposed to different strategies of EOP high-energy radiation. Plants were grown for 24 days under an average daily light integral (DLI) of $15.8 \mathrm{~mol} \cdot \mathrm{m}^{-2} \cdot \mathrm{d}^{-1}\left(220 \mu \mathrm{mol} \cdot \mathrm{m}^{-2} \cdot \mathrm{s}^{-1}\right.$ for $\left.20 \mathrm{~h} \cdot \mathrm{d}^{-1}\right)$ using red:blue lightemitting diode (LED) lamps. Four days before harvest (36 days after sowing), plants were exposed to one of three EOP treatments added to red:blue LEDs: 1) ultraviolet-A (EOPultraviolet); 2) high blue (EOP-B); or 3) high-intensity (EOP-H) radiation. A fourth treatment was included as a control, with no EOP. Except for EOP-H, all treatments provided a DLI of $15.8 \mathrm{~mol} \cdot \mathrm{m}^{-2} \cdot \mathrm{d}^{-1}$; EOP-H provided a DLI of $31.7 \mathrm{~mol} \cdot \mathrm{m}^{-2} \cdot \mathrm{d}^{-1}$. No treatment differences were measured for shoot fresh weight $(F W)$ of 'Rouxaï $R Z$ ' but shoot FW of 'Codex RZ' was negatively affected by EOP radiation, indicating potential changes in lettuce yield from applying EOP high-energy radiation during active plant growth. In general, EOP treatments did not affect total phenolic content and total carotenoid concentration of plants, but anthocyanin content and antioxidant capacity were positively influenced by EOP-B and EOP-H, whereas EOP-ultraviolet resulted in similar nutritional quality to control. Findings from this study indicate that EOP highenergy radiation, especially EOP-B, has significant potential to improve the nutritional quality of red-leaf lettuce grown in controlled environments.
\end{abstract}

Salad greens such as lettuce (Lactuca sativa) are the most common crop type produced in indoor farms (also known as plant factories or vertical farms) because of their relatively short production cycle, small size,

Received for publication 18 Mar. 2020. Accepted for publication 28 Apr. 2020.

Published online 1 June 2020.

This work was supported by the U.S. Department of Agriculture (USDA), National Institute of Food and Agriculture, Multistate Research Project NE1835: Resource Optimization in Controlled Environment Agriculture; and it is partially funded by Kalera, Inc.

We thank Cristian Toma for his assistance with experimental planning, Bala Rathinasabapathi for his critical review to improve the quality of this manuscript, and Maria Fernanda do Amaral Trientini and Kailey Tank for experimental and technical assistance.

C.G. is the corresponding author. E-mail: cgomezv (a) ufl.edu.

This is an open access article distributed under the CC BY-NC-ND license (https://creativecommons. org/licenses/by-nc-nd/4.0/). stress, radiation quantity [i.e., photosynthetic photon flux $(P P F)]$ and quality (i.e., color, wavelength) are key regulators of different nutritional compounds that can be easily adjusted in controlled environments (Folta, 2019). In addition to promoting biomass production, high $P P F \mathrm{~s}$ can increase secondary metabolites in lettuce, but effects may differ between green- and red-leaf cultivars (Gent, 2014; Pérez-López et al., 2013, 2014, 2018; Voipio and Autio, 1995; Woltering and Witkowska, 2016; Yan et al., 2019). Furthermore, high-energy radiation with ultraviolet-B (280 to $315 \mathrm{~nm}$ ), ultraviolet-A ( 315 to $400 \mathrm{~nm}$ ), and blue (400 to $500 \mathrm{~nm}$ ) wavebands has been shown to increase product quality in many plant species (Carvalho and Folta, 2014; Samuolienè et al., 2017).

Although numerous studies have evaluated the effect of high-energy radiation as a means to increase the nutritional quality of lettuce, most studies have focused on providing constant radiation quantities or qualities throughout the production cycle (Caldwell and Britz, 2006; Li and Kubota 2009; Lin et al., 2013; Ohashi-Kaneko et al., 2007; Viršile et al., 2020; Woltering and Witkowska, 2016). However, constantly providing high-energy ultraviolet or blue radiation can negatively affect plant morphology and the overall yield of lettuce (Dougher and Bugbee, 2004; Wargent et al., 2009). Similarly, using high $P P F \mathrm{~s}$ can increase production costs associated with sole-source lighting and may induce undesirable photo-oxidative stress (Murchie and Niyogi, 2011; Samuoliené; et al., 2009).

EOP radiation is a cost-effective, preharvest solution to increase the nutritional quality of plant products and thus increase market value without negatively affecting yield. EOP is achieved by exposing plants to supplemental radiation, typically acting as an induced stressor, near the end of the cropping cycle after sufficient growth has already occurred. Previous studies have reported increases in lettuce quality with EOP compared with plants grown under a constant spectrum or $P P F$. However, most research evaluating the effect of EOP on plant quality has focused on greenhouse production (Owen and Lopez, 2015; Samuolienè et al., 2012; Viršile et al., 2018; Zhang et al., 2019; Žukauskas et al., 2011). Fewer studies have evaluated the effects of EOP using sole-source lighting indoors; and to our knowledge, none have compared the use of high-energy wavebands (Nicole et al., 2016, 2019a, 2019b) vs. higher PPFs (Oh et al., 2009; Pérez-López et al., 2018; Zhou et al., 2012). Therefore, our objective was to quantify and compare growth and accumulation of secondary metabolites from two red-leaf lettuce cultivars grown indoors and exposed to different strategies of EOP high-energy radiation. We hypothesized that EOP treatments would not affect plant growth, but that EOP with high-energy wavebands would increase phytochemical accumulation more than EOP, with a high $P P F$. 


\section{Materials and Methods}

Plant material and growing conditions. Seeds of 'Codex RZ' and 'Rouxaï RZ' lettuce (Rijk Zwaan, De Lier, The Netherlands) were pregerminated for $48 \mathrm{~h}$ in a laboratory and subsequently transplanted into 98-plug sheets (55 mL individual cell volume) of rockwool (A-Ok starter plugs; Grodan, Roermond, The Netherlands). Seedlings were grown for $10 \mathrm{~d}$ inside a walk-in growth chamber (C6 Control System with EcoSys Software; Environmental Growth Chambers, Chagrin Falls, OH) using an average DLI of $\approx 13 \mathrm{~mol} \cdot \mathrm{m}^{-2} \cdot \mathrm{d}^{-1}$ $\left(150 \pm 5 \mu \mathrm{mol} \cdot \mathrm{m}^{-2} \cdot \mathrm{s}^{-1}\right.$ for $\left.24-\mathrm{h} \cdot \mathrm{d}^{-1}\right)$ provided by red:blue LED lamps (GreenPower; Signify, Somerset, NJ) with peak wavelengths of 660 and $448 \mathrm{~nm}$, which delivered $87 \%$ red (600 to $700 \mathrm{~nm}$ ) and $13 \%$ blue radiation as measured with a spectroradiometer (SS-110; Apogee Instruments Inc., Logan, UT). Ambient temperature and relative humidity $(\mathrm{RH})$ were set at $24{ }^{\circ} \mathrm{C}$ and $70 \%$, respectively; $\mathrm{CO}_{2}$ concentration was maintained at ambient levels $\left(405 \mu \mathrm{mol} \cdot \mathrm{mol}^{-1}\right)$. Seedlings were sub-irrigated as needed with tap water that had an electrical conductivity (EC) of 0.4 $\mathrm{mS} \cdot \mathrm{cm}^{-1}$, a $\mathrm{pH}$ of 8.3 , and $40 \mathrm{mg} \cdot \mathrm{L}^{-1}$ calcium carbonate $\left(\mathrm{CaCO}_{3}\right)$.

At $12 \mathrm{~d}$ after sowing, three uniform seedlings per cultivar were transplanted into a single deep-water culture hydroponic system using 5-cm diameter net cups. Each cylindrical 7.6-L hydroponic system had a white plastic lid with three openings $(25 \mathrm{~cm}$ apart) that held one net cup each. Plastic barriers were placed inside each reservoir to separate the plant roots. A clear plastic tube attached to an air pump (320 GPH, Dual Diaphragm Air Pump; General Hydroponics, Santa Rosa, CA) provided continuous aeration to the nutrient solution. Plants were grown for $24 \mathrm{~d}$ inside two walk-in growth chambers (C6 Control System), each equipped with two opposite shelving units with two compartments $(61-\mathrm{cm}$ wide $\times 183-\mathrm{cm}$ long $\times 94-\mathrm{cm}$ high) that held four hydroponic systems per cultivar. Each compartment had red:blue LED lamps (GreenPower) that provided an average DLI of $15.8 \mathrm{~mol} \cdot \mathrm{m}^{-2} \cdot \mathrm{d}^{-1}$ (PPF $220 \pm$ $\mu \mathrm{mol} \cdot \mathrm{m}^{-2} \cdot \mathrm{s}^{-1} ; 20$-h photoperiod from 0200 to $2200 \mathrm{HR}$ ). A white shade screen was used as a curtain $(215-\mathrm{cm}$ long $\times 200-\mathrm{cm}$ high) to prevent radiation pollution between the two opposite shelves in each chamber. Average ambient day (from 0200 to $2200 \mathrm{HR}$ ) and night (from 2200 to $0200 \mathrm{HR}$ ) air temperature of the chambers were set at $22{ }^{\circ} \mathrm{C}$ and $21{ }^{\circ} \mathrm{C}$, respectively. The $\mathrm{CO}_{2}$ concentration and $\mathrm{RH}$ were set at $405 \mu \mathrm{mol} \cdot \mathrm{mol}^{-1}$ and $70 \%$, respectively. Plants were grown using a commercial water-soluble fertilizer (OASIS Hydroponic Fertilizer 16-4-17; Oasis Grower Solutions, Kent, $\mathrm{OH}$ ) dissolved in tap water at a concentration of $150 \mathrm{mg} \cdot \mathrm{L}^{-1} \mathrm{~N}$ (EC and $\mathrm{pH}=\approx 1.2 \mathrm{dS} \cdot \mathrm{m}^{-1}$ and 6.0 , respectively). The nutrient solution was refilled with tap water as needed and completely replaced after 2 weeks. Two fans were placed above plant canopy height within each treatment compartment, providing constant air flow to min- imize tip burn incidence. Before applying the EOP treatments, all hydroponic systems were randomly rotated three times per week within each chamber to minimize location effects.

Treatments. Treatments were applied $36 \mathrm{~d}$ after sowing by exposing plants under each compartment to $4 \mathrm{~d}$ of the following: 1) $11 \pm$ $1 \mu \mathrm{mol} \cdot \mathrm{m}^{-2} \cdot \mathrm{s}^{-1}$ of ultraviolet-A radiation provided by LED lamps (RAY66; Fluence Bioengineering, Austin, TX; peak wavelength of $405 \mathrm{~nm}$ ) where an additional $55 \pm 1 \mu \mathrm{mol} \cdot \mathrm{m}^{-2} \cdot \mathrm{s}^{-1}$ were counted as $P P F$ of blue wavebands + $165 \pm 3 \mu \mathrm{mol} \cdot \mathrm{m}^{-2} \cdot \mathrm{s}^{-1}$ from red:blue LED lamps (EOP-ultraviolet); 2) additional blue radiation with $120 \pm 2 \mu \mathrm{mol} \cdot \mathrm{m}^{-2} \cdot \mathrm{s}^{-1}$ provided by blue LED lamps (RAY66; peak wavelength of $450 \mathrm{~nm})+100 \pm 2 \mu \mathrm{mol} \cdot \mathrm{m}^{-2} \cdot \mathrm{s}^{-1}$ from red:blue LED lamps (EOP-B); 3) high intensity radiation with $440 \pm 3 \mu \mathrm{mol} \cdot \mathrm{m}^{-2} \cdot \mathrm{s}^{-1}$ from red:blue LED lamps (EOP-H); or 4) $220 \pm 1 \mu \mathrm{mol} \cdot \mathrm{m}^{-2} \cdot \mathrm{s}^{-1}$ from red:blue LED lamps as a control with no EOP. Except for EOP-H, all treatments provided a DLI of 15.8 $\mathrm{mol} \cdot \mathrm{m}^{-2} \cdot \mathrm{d}^{-1}\left(220 \pm 2 \mu \mathrm{mol} \cdot \mathrm{m}^{-2} \cdot \mathrm{s}^{-1}\right.$ of $P P F$; 20-h photoperiod from 0200 to $2200 \mathrm{HR}$ ); EOP-H provided a DLI of $31.7 \mathrm{~mol} \cdot \mathrm{m}^{-2} \cdot \mathrm{d}^{-1}$ (PPF $440 \pm 3 \mu \mathrm{mol} \cdot \mathrm{m}^{-2} \cdot \mathrm{s}^{-1} ; 20$-h photoperiod from 0200 to $2200 \mathrm{HR}$ ). The radiation output to achieve target $P P F \mathrm{~s}$ and a uniform spectral distribution were controlled by adjusting the number of red:blue LED lamps or dimmer settings from each ultraviolet or blue LED lamp. The spectral distribution of the lamps is shown in Fig. 1 and the spectral characteristics of each treatment (combining output from different lamps) are described in Table 1.

Measurements and data collected. For each cultivar, one plant per hydroponic system per treatment was destructively harvested $40 \mathrm{~d}$ after sowing. Plants were weighed with an electronic balance to obtain shoot FW. Tissue samples were then collected from the sixth and seventh fully expanded leaves within each plant. Tissue samples were flash-frozen in liquid nitrogen and immediately placed in a freezer at $-80{ }^{\circ} \mathrm{C}$. The freeze-dried samples were used to determine dry weight (DW), and an adjusted extraction protocol described by Rodriguez-Saona and Wrolstad (2001) was used to process samples for anthocyanin, antioxidant capacity, and total phenolic content (TPC) following the procedures below. Frozen tissue samples (1 g of FW) were ground using a mortar with liquid nitrogen, and then extracted and re-extracted using 10 $\mathrm{mL}$ of acidified methanol $(30 \mathrm{~mL}$ of $88 \%$ to $91 \%$ formic acid $+370 \mathrm{~mL}$ deionized water + $600 \mathrm{~mL}$ of $99.9 \%$ methanol) for $20 \mathrm{~min}$.

The extracted sample was centrifuged, and its supernatant was used to determine total monomeric anthocyanin pigment content according to Lee et al. (2005) with some modifications. For each sample, $600-\mu \mathrm{L}$ aliquots were diluted to $3 \mathrm{~mL}$ with a potassium chloride buffer $(0.025 \mathrm{M}, \mathrm{pH} 1.0)$ and a sodium acetate buffer ( $0.4 \mathrm{M}, \mathrm{pH} 4.5)$. After $15 \mathrm{~min}$, the absorbance was measured at $510 \mathrm{~nm}$ with a spectrophotometer (SpectraMax Plus 384; Molecular Devices, Sunnyvale, CA). In addition, absorbance was measured at $700 \mathrm{~nm}$ for haze correction. The total monomeric anthocyanin content was expressed as milligrams of cyanidin-3glucoside equivalents per gram of DW.

Antioxidant capacity was determined using the ferric-reducing antioxidant power (FRAP) assay following a modified protocol described by Benzie and Strain (1996). A fresh FRAP solution was prepared by mixing with $25 \mathrm{~mL}$ of a $0.3 \mathrm{M}$ sodium acetate buffer (pH 3.6), $2.5 \mathrm{~mL}$ of $10 \mathrm{~mm}$ 2,4,6-Tri (2-pyridyl)-s-triazine solution in $40 \mathrm{~mm}$ of hydrochloric acid that was previously prepared, and $2.5 \mathrm{~mL}$ of $20 \mathrm{~mm}$ ferric chloride. A $4-\mu \mathrm{L}$ aliquot of the sample extract was mixed with $1 \mathrm{~mL}$ of the FRAP reagent (warmed up to $37^{\circ} \mathrm{C}$ ) and incubated during $30 \mathrm{~min}$ in a warm bath. Absorbance was measured at $593 \mathrm{~nm}$ using a spectrophotometer; acidified methanol (extract solvent) was used as a blank. The calibration curve was obtained using a series of ferrous sulfate heptahydrate ranging from 2 to $20 \mathrm{~mm}$. Antioxidant capacity was reported as millimolars ferrous iron $\left(\mathrm{Fe}^{2+}\right)$ equivalents per gram of DW.

TPC was determined using the method described by Ainsworth and Gillespie (2007) using a Folin-Ciocalteau $(\mathrm{F}-\mathrm{C})$ reagent. A $100-\mu \mathrm{L}$ aliquot of the sample supernatant was mixed with $200 \mu \mathrm{L}$ of $10 \%(\mathrm{v} / \mathrm{v}) \mathrm{F}-\mathrm{C}$ reagent vortexed thoroughly, after which $800 \mu \mathrm{L}$ of $700 \mathrm{~mm}$ sodium carbonate were added. After incubating for $2 \mathrm{~h}$ at room temperature, absorbance was measured using a spectrophotometer at $765 \mathrm{~nm}$. Methanol was used as a blank, and TPC was calculated using a standard curve with multiple gallic acid concentrations and expressed as milligrams of gallic acid equivalents per gram of DW.

The extraction and determination of total carotenoids (xanthophylls and carotenes) was conducted following a modified protocol described by Lichtenthaler and Buschmann (2001). A total of $50 \mathrm{mg}$ of fresh leaf tissue were ground in a mortar with liquid nitrogen, adding $150 \mathrm{mg}$ of magnesium oxide to avoid pheophytin formation. The ground sample was extracted with $5 \mathrm{~mL}$ of $100 \%$ acetone and after centrifugation, absorbance of the supernatant was measured at $750,662,645,520$, and $470 \mathrm{~nm}$ using a spectrophotometer. Concentrations of carotenoids were determined by the following equations:

$$
\begin{aligned}
& \mathrm{c}_{a}(\mu \mathrm{g} / \mathrm{mL})=12.25 \mathrm{~A}_{663.2}-2.79 \mathrm{~A}_{646.8} \\
& \mathrm{c}_{b}(\mu \mathrm{g} / \mathrm{mL})=21.50 \mathrm{~A}_{646.8}-5.10 \mathrm{~A}_{663.2} \\
& \mathrm{c}_{(x+c)}(\mu \mathrm{g} / \mathrm{mL}) \\
& \quad=\left(1000 \mathrm{~A}_{470}-1.82 \mathrm{c}_{a}-85.02 \mathrm{c}_{b}\right) / 198
\end{aligned}
$$

Total carotenoids were expressed as milligrams of carotenoids per gram of DW.

Nitrate content was measured by using samples extracted from $1 \mathrm{~g}$ of fresh leaf tissue ground in a mortar with liquid nitrogen and 6 $\mathrm{mL}$ of deionized water. The mixture was centrifuged for $15 \mathrm{~min}$, and $200 \mu \mathrm{L}$ of precipitate was mixed with $800 \mu \mathrm{L}$ of $5 \%$ (w/v) 
Table 1. Spectral characteristics of end-of-production treatments delivered by red:blue light-emitting diode lamps with or without (control) ultraviolet-A (EOPultraviolet), additional blue (EOP-B), or high-intensity (EOP-H) radiation. ${ }^{2}$

\begin{tabular}{|c|c|c|c|c|c|c|c|}
\hline Treatment & $\begin{array}{l}\text { Photosynthetic photon } \\
\text { flux }(P P F)\end{array}$ & $\begin{array}{c}\text { Ultraviolet-A } \\
(350-400 \mathrm{~nm})\end{array}$ & $\begin{array}{c}\text { Blue } \\
(400-500 \mathrm{~nm})\end{array}$ & $\begin{array}{c}\text { Green } \\
(500-600 \mathrm{~nm})\end{array}$ & $\begin{array}{c}\text { Red } \\
(600-700 \mathrm{~nm})\end{array}$ & $\begin{array}{l}\text { Total photon } \\
\text { flux }(T P F)\end{array}$ & $\begin{array}{l}\text { Yield photon } \\
\text { flux }(Y P F)^{\mathrm{y}}\end{array}$ \\
\hline EOP-B & $220 \pm 2$ & $0.2(0 \%)$ & $152(69 \%)$ & $0.3(0 \%)$ & $68(31 \%)$ & $220 \pm 2$ & 179 \\
\hline EOP-H & $440 \pm 3$ & $0.2(0 \%)$ & $53(13 \%)$ & $0.2(0 \%)$ & $387(87 \%)$ & $440 \pm 3$ & 397 \\
\hline
\end{tabular}

${ }^{\mathrm{z}}$ Photon flux densities over 1-nm increments were integrated as $P P F(400-700 \mathrm{~nm})$ and $T P F(350-700 \mathrm{~nm})$, which includes ultraviolet-A radiation. Numbers outside of parentheses represent photon flux densities in $\mu \mathrm{mol} \cdot \mathrm{m}^{-2} \cdot \mathrm{s}^{-1}$. Numbers in parentheses represent percentages of each waveband's contribution to $T P F$. ${ }^{\mathrm{y}} Y P F$ is the product of $P P F$ and relative quantum efficiency calculated based on McCree (1972) and Sager et al. (1988).

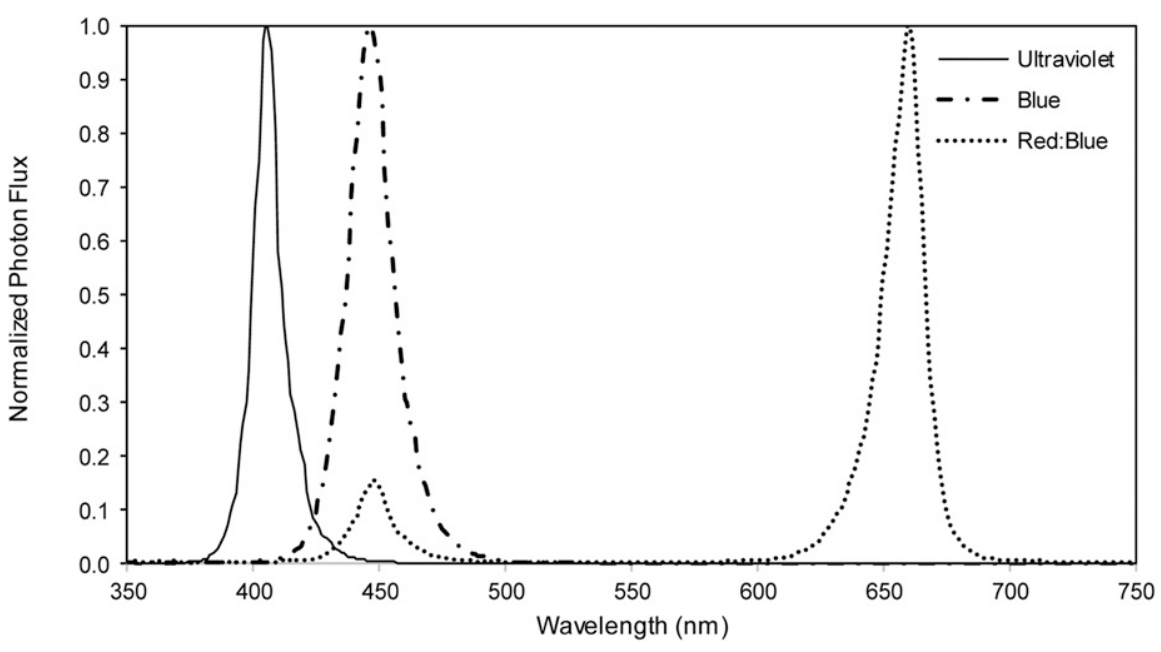

Fig. 1. Normalized spectral power distribution of the lamps used in the experiment. Photon flux $\left(\mu \mathrm{mol} \cdot \mathrm{m}^{-2}\right.$ $\cdot \mathrm{s}^{-1}$ ) was measured for every $1 \mathrm{~nm}$.

salicylic acid dissolved in sulfuric acid for $20 \mathrm{~min}$ at room temperature, after which 19 $\mathrm{mL}$ of $2 \mathrm{~N}$ sodium hydroxide was added slowly. After allowing the samples to cool at room temperature for $\approx 30 \mathrm{~min}$, absorbance was measured at $410 \mathrm{~nm}$ using a spectrophotometer. Nitrate content determination was performed according to the method of Cataldo et al. (1975) with some modifications. Calculations were made based on the measured absorbance and the nitrate calibration curve, using potassium nitrate as a standard. Nitrates were reported as milligrams of nitrate-nitrogen equivalents per kilogram of $\mathrm{FW}$.

Experimental design and statistical analysis. The experiment was replicated twice over time; and within replication, each chamber was considered one block with four shelves used as treatment replications. Data were analyzed with JMP (version 12; SAS Institute Inc., Cary, NC) as a randomized complete block design with four blocks (two replications in time and two replications in space) and four sub-samples (hydroponic systems) for each cultivar per treatment per block. Results were pooled between replications over time, because the variances between experiments were not different and the statistical interactions between treatment and replication were not significant $(P \geq 0.05)$. The influence of the two different categorical independent variables (i.e., cultivar and treatment), and their possible interaction on each of the continuous dependent variables were analyzed by using a two-way analysis of variance (Table 2). Data collected are presented as main effects $(n=8)$ except for shoot FW, in which the two cultivars are presented separately $(n=4)$ because of the significant cultivar $\times$ treatment interaction $(P \geq 0.05)$. Mean separation was performed using Tukey's honestly significant difference test at $P<0.05$. In addition, cultivar differences are presented in Table 3 for TPC, antioxidant capacity, and total carotenoids ( $\mathrm{n}=16)$; mean separation was based on Student's $t$ test at $P \leq 0.05$.

\section{Results and Discussion}

No treatment differences were measured for shoot FW of 'Rouxaï RZ', which ranged from 67 to $76 \mathrm{~g}$ across treatments (Fig. 2A). However, shoot FW of 'Codex RZ' was negatively affected by EOP radiation, because control plants had between $11 \%$ and $37 \%$ more FW than those treated with EOPsuggesting that plants were still growing when treatments were applied. Correspondingly, 'Codex RZ' plants exposed to EOP-H, which received double the DLI during the EOP treatment, produced $50 \mathrm{~g}$ more than those exposed to EOP-ultraviolet. Many studies have shown that higher DLIs linearly increase growth and yield for crops with high-harvest indexes, such as lettuce. In a study evaluating radiation requirements for indoor gardening, Paz et al. (2019) concluded that higher DLIs during the finishing stage increased growth, nutritional quality, and visual appeal of indoor-grown red-leaf lettuce, which corresponds with our findings for EOP-H. Furthermore, others have shown that ultraviolet radiation can reduce biomass accumulation in lettuce, most likely as a response to the high metabolic cost of accumulating photoprotective secondary metabolites (Tsormpatsidis et al., 2008). It is likely that delaying EOP radiation treatments until after 'Codex RZ' plants had surpassed the exponential growth phase would have minimized the differences in the shoot FW measured in our study.

Anthocyanin content was more than double in plants treated with EOP-B or EOP-H compared with those treated with EOPultraviolet or control (Fig. 2B). Similarly, the highest antioxidant capacity was measured in plants exposed to EOP-B, which was $61 \%$ and $47 \%$ higher than that produced under EOP-ultraviolet and control, respectively (Fig. 2C). Several studies have reported measurable increases in lettuce quality under different wavebands of EOP (Nicole et al., 2016, 2019a, 2019b; Owen and Lopez, 2015; Samuolienè et al., 2012; Viršilè et al., 2018; Zhang et al., 2019). In addition, Pérez-López et al. (2018) found that $700 \mu \mathrm{mol} \cdot \mathrm{m}^{-2} \cdot \mathrm{s}^{-1}$ of EOP radiation provided by warm-white fluorescent lamps increased accumulation of antioxidant capacity in green- and red-leaf lettuce plants compared with those grown under a constant $P P F$ of $400 \mu \mathrm{mol} \cdot \mathrm{m}^{-2} \cdot \mathrm{s}^{-1}$. Žukauskasa et al. (2011) suggested that EOP radiation can affect the accumulation of bioactive compounds in lettuce as an indirect response to preharvest changes in metabolic activity against photo-oxidative stress, essentially acting a protective scavenger against harmful radiation.

Like our findings (Fig. 2B and C), the results of Li and Kubota (2009) showed that blue radiation has a higher capacity to increase anthocyanin content and antioxidant capacity in lettuce compared with ultraviolet radiation. A likely explanation for the significant differences in anthocyanin content and antioxidant capacity measured in our study between EOP-B and EOP-ultraviolet could be related to the different contributions of blue radiation from both treatments (Table 1), with EOP-B providing twice the amount of blue photons compared with EOP-ultraviolet. Although ultraviolet exposure typically triggers the synthesis of ultraviolet-blocking pigments that prevent high-energy radiation from inducing damage via the generation of reactive oxygen species (Murchie and Niyogi, 
2011), photo-oxidative stress responses to EOP-ultraviolet could have been limited by the overall lower dosage of high-energy photons compared with that provided by EOP-B. It is also plausible that the ultraviolet dose used in our study was not sufficient to maximize the accumulation of some antioxidant enzymes that contribute to lettuce quality improvements. For example, others have reported increases in proline content with highenergy blue wavebands, which help mitigate stress responses in plants by acting as an osmoregulatory compound that helps stabilize proteins when plants are exposed to stress

Table 2. Significance level of growth and quality parameters measured from 'Codex RZ' and 'Rouxaï RZ' red-leaf lettuce plants grown indoors and exposed to different end-of-production high-energy radiation treatments. $^{\mathrm{z}}$

\begin{tabular}{|c|c|c|c|c|c|c|}
\hline \multirow[b]{2}{*}{ Source } & \multicolumn{6}{|c|}{ Variable } \\
\hline & $\begin{array}{l}\text { Shoot } \\
\text { fresh wt }\end{array}$ & Anthocyanin & $\begin{array}{l}\text { Antioxidant } \\
\text { capacity }\end{array}$ & $\begin{array}{l}\text { Total phenolic } \\
\text { content }\end{array}$ & Carotenoids & Nitrate \\
\hline Replication & NS & NS & NS & NS & NS & NS \\
\hline Cultivar & $* * *$ & NS & * & * & $* * *$ & NS \\
\hline Treatment & $* * *$ & * & * & NS & NS & $* *$ \\
\hline Treatment $x$ & $* *$ & NS & NS & NS & NS & NS \\
\hline
\end{tabular}

Cultivar

${ }^{\mathrm{z}}$ Treatments were delivered by red:blue light-emitting diode lamps with or without (control) ultraviolet-A, additional blue, or high-intensity radiation.

Ns, ${ }^{*}, * * * *$ Nonsignificant or significant at $P \leq 0.05,0.01$, or 0.001 , respectively.

Table 3. Quality parameters measured from two red-leaf lettuce cultivars grown indoors and exposed to different end-of-production (EOP) high-energy radiation treatments. ${ }^{\mathrm{z}}$

\begin{tabular}{lccc}
\hline Cultivar & $\begin{array}{c}\text { Antioxidant capacity } \\
(\mathrm{mm} / \mathrm{g} \mathrm{DW})\end{array}$ & $\begin{array}{c}\text { Total phenolic content } \\
(\mathrm{mg} / \mathrm{g} \mathrm{DW})\end{array}$ & $\begin{array}{c}\text { Carotenoids } \\
(\mathrm{mg} / \mathrm{g} \mathrm{DW})\end{array}$ \\
\hline Codex RZ & $0.47 \mathrm{~b}^{\mathrm{y}}$ & $17.5 \mathrm{~b}$ & $4.8 \mathrm{a}$ \\
Rouxaï RZ & $0.59 \mathrm{a}$ & $22.0 \mathrm{a}$ & $3.9 \mathrm{~b}$ \\
\hline
\end{tabular}

${ }^{\mathrm{z}}$ Data represent a pooled average for plants exposed to EOP treatments delivered by red:blue light-emitting diode lamps with or without ultraviolet-A, additional blue, or high-intensity radiation $(n=16)$.

${ }^{\mathrm{y}}$ Means within column followed by the same letter are not different based on Student's $t$ test at $P \leq 0.05$.

(Carvalho and Folta, 2014; Zheng and Van Labeke, 2017). In contrast, proline content in lettuce has been reported to be unaffected by ultraviolet radiation (Rajabbeigi et al., 2013). Karvansara and Razavi (2019) concluded that proline production is promoted only at relatively high doses of ultraviolet in some plants, which could help explain the smaller treatment effects measured with EOP-ultraviolet compared with EOP-B.

Khare and Guruprasad (1993) suggested that ultraviolet- $\mathrm{B}$ radiation is more effective than ultraviolet-A at enhancing anthocyanin accumulation in plants. However, application of shorter waveband ultraviolet in commercial production facilities may require significant precautions for workers' safety. Additionally, lamps with ultraviolet LEDs are still expensive, and their efficiency can be considerably limited compared with that of LEDs with longer peak wavelengths (Bugbee, 2017). As stated by Mitchell and Sheibani (2020), forthcoming breakthroughs in ultraviolet LED efficiency and efficacy, information from studies to be conducted with ultraviolet, and advancement of technologies to ensure worker safety with ultraviolet radiation may enable the widespread use of EOP-ultraviolet in the future. For now, based on our findings, EOP with additional blue radiation could be considered a more effective strategy to increase anthocyanin content and antioxidant capacity of indoor-grown red-leaf lettuce
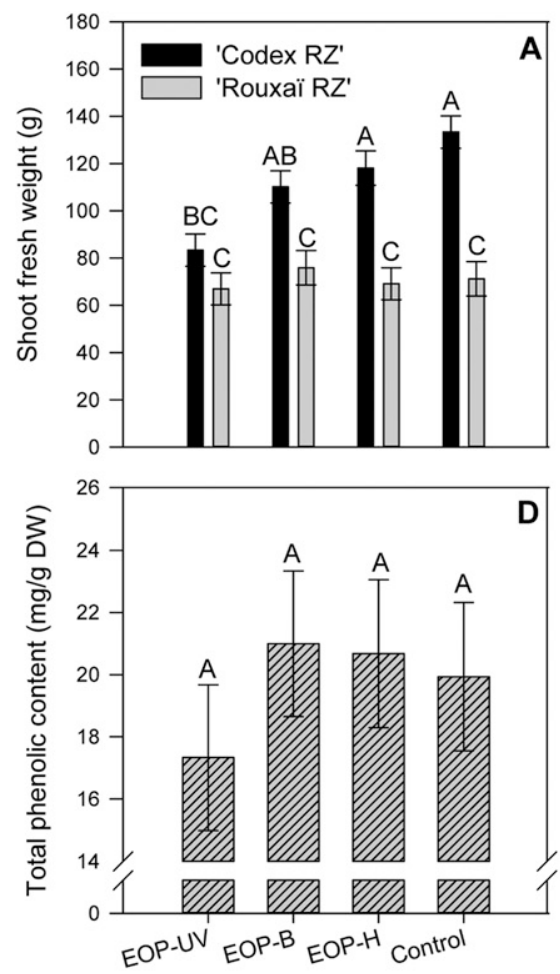
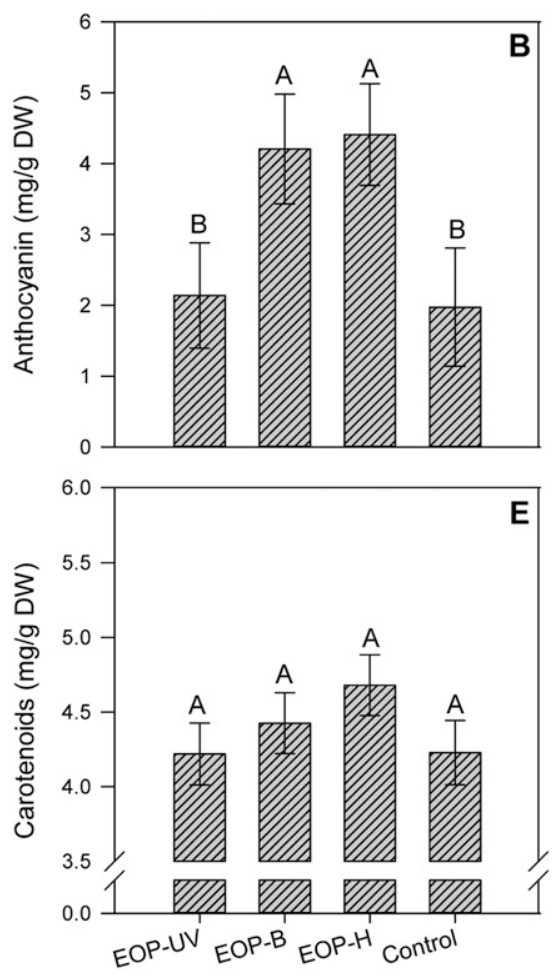

Treatments
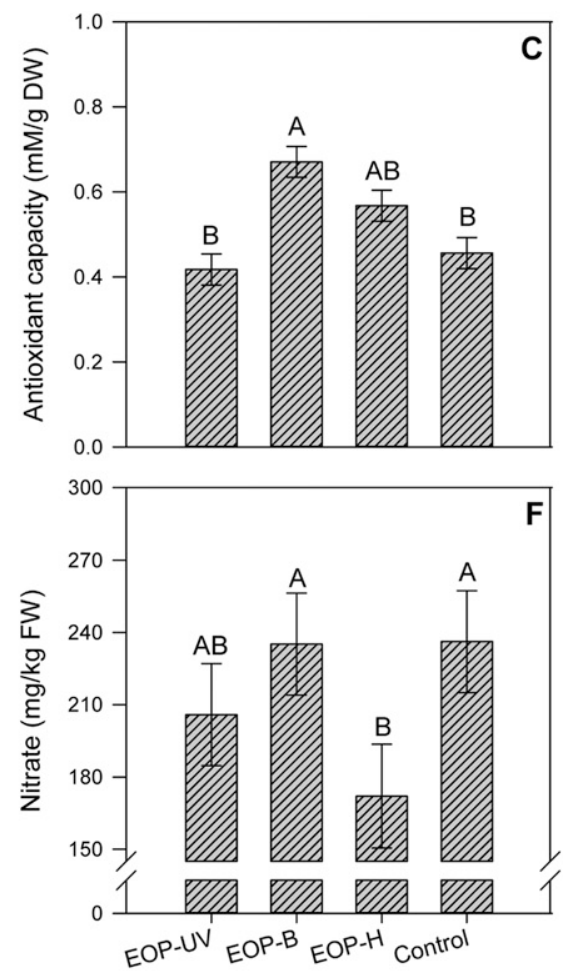

Fig. 2. Growth (A) and quality (B-F) parameters measured from 'Codex RZ' and 'Rouxaï RZ' red-leaf lettuce plants exposed to end-of-production treatments delivered by red:blue light-emitting diode lamps with or without (control) ultraviolet-A (EOP-UV), additional blue (EOP-B), or high-intensity (EOP-H) radiation. Except for shoot fresh weight $(n=4)$, bars represent the mean \pm SE of four replications and two cultivars $(n=8)$. Means within graphs with the same letter are not different based on Tukey's honestly significant difference test at $P \leq 0.05$. 
plants compared with EOP-ultraviolet (Fig. 2B and $\mathrm{C}$ ). Furthermore, while EOP-H can positively affect lettuce quality, providing high $P P F$ s can be more energetically expensive than exposing plants to high-energy blue wavebands.

For both cultivars, EOP treatments did not significantly affect TPC, but the general trend shows that plants exposed to EOP-ultraviolet had lower TPC compared with those treated with EOP-B or EOP-H (Table 2, Fig. 2D). The lack of significant treatment differences was unexpected, as radiation-quality responses to TPC tend to follow similar trends as those from antioxidant activities (Carvalho and Folta, 2014; Li and Kubota, 2009; Mulabagal et al., 2010; Oh et al., 2009; Son and Oh, 2013). Furthermore, Pérez-López et al. (2018) and Oh et al. (2009) reported significant increases in the accumulation of phenolic compounds when lettuce plants were exposed to EOP-H. It is likely that the shortterm treatments used in this study were not sufficient to induce an increased synthesis of phenolic compounds. In contrast, cultivar effects indicated that 'Rouxai RZ' plants had significantly higher antioxidant capacity and TPC than 'Codex RZ' plants (Table 3). It is not uncommon for net changes in lettuce quality to be cultivar-specific, which may be more pronounced in plants with lower basal antioxidant capacities (Llorach et al., 2008; Pérez-López et al., 2014; Žukauskas et al., 2011). Therefore, genetic variability is most likely responsible for the differences measured for antioxidant capacity and TPC between the two cultivars used in our study.

No treatment effect was measured for total carotenoid concentration; but in general, values were similar under EOP-ultraviolet and control, which were slightly lower than those measured under EOP-B or EOP-H (Table 2, Fig. 2E). Although others have shown higher carotenoid concentration in lettuce with blue and/or red LEDs compared with white radiation (Carvalho and Folta, 2014; Johkan et al., 2010; Li and Kubota, 2009), red-leaf lettuce plants are known to produce lower carotenoid concentration than green-leaf or romaine lettuce (Mou, 2005). Accordingly, we found that 'Codex RZ' plants had more total carotenoids than 'Rouxaï RZ' (Table 3), which could be related to the greener shoot pigmentation observed in that cultivar (data not shown). There seems to be significant genetic variation in carotenoid concentration among different lettuce genotypes (Mou, 2005). Thus, lack of treatment differences and significant cultivar effects for total carotenoid concentration may be related to the specific genetics of the cultivars used in our study.

Plants treated EOP-B or control had 37\% higher nitrate content than those exposed to EOP-H (Fig. 2F). In accordance with our findings, others have shown that higher $P P F \mathrm{~s}$ tend to reduce nitrate accumulation in lettuce leaves (Bian et al., 2018; Blom-Zandstra and Lampe, 1985; Escobar-Gutierrez et al., 2002; Paz et al., 2019; Samuoliene et al., 2009). In contrast, blue radiation has been reported to increase nitrate content of plants (Carvalho and Folta, 2014). High nitrate content is often considered a negative quality attribute of lettuce (Bruning-Fann and Kaneene, 1993); and although data on the potential long-term health risk of nitrate are contradictory (Gangolli et al., 1994; Walker, 1990), regulatory agencies are setting maximum-allowed nitrate levels in vegetables (Santamaria, 2006). Accordingly, recommended levels for nitrate content in lettuce range between 3000 to 5000 $\mathrm{mg} \cdot \mathrm{kg}^{-1}$ of FW (Colonna et al., 2016), which are an order of magnitude above the values measured in any of our treatments. Therefore, although nitrate content was differently affected by EOP radiation, all plants had acceptable levels for human consumption.

In conclusion, no treatment differences were measured for shoot FW of 'Rouxaï RZ', but shoot FW of 'Codex RZ' was negatively affected by EOP radiation, indicating potential changes in yield when applying EOP high-energy radiation during active plant growth. In general, EOP treatments did not affect TPC and carotenoid concentration of plants; but anthocyanin content and antioxidant capacity were positively influenced by EOP-B and EOP-H, whereas EOP-ultraviolet resulted in similar nutritional quality to control. Cultivar differences indicated that 'Rouxaï RZ' plants have a higher antioxidant capacity and accumulate more TPC than 'Codex RZ', but the opposite cultivar trend was measured for total carotenoid concentration. Based on our findings and considering potential implications on production costs, EOP with additional blue radiation is a more effective strategy to increase anthocyanin content and antioxidant capacity of indoorgrown red-leaf lettuce plants than EOP-H and EOP-ultraviolet.

\section{Literature Cited}

Ainsworth, E.A. and K.M. Gillespie. 2007. Estimation of total phenolic content and other oxidation substrates in plant tissues using Folin-Ciocalteu reagent. Nat. Protoc. 2:875877.

Benzie, I.F. and J.J. Strain. 1996. The ferric reducing ability of plasma (FRAP) as a measure of "antioxidant power": The FRAP Assay. Anal. Biochem. 239:70-76.

Bian, Z., R. Cheng, Y. Wang, Q. Yang, and C. Lu. 2018. Effect of green light on nitrate reduction and edible quality of hydroponically grown lettuce (Lactuca sativa L.) under short-term continuous light from red and blue lightemitting diodes. Environ. Exp. Bot. 153:63-71.

Blom-Zandstra, M. and J.E.M. Lampe. 1985. The role of nitrate in the osmoregulation of lettuce (Lactuca sativa L.) grown at different light intensities. J. Expt. Bot. 36:1043-1052.

Bruning-Fann, C.S. and J.B. Kaneene. 1993. The effects of nitrate, nitrite and N-nitroso compounds on human health: A review. Vet. Hum. Toxicol. 35:521-538.

Bugbee, B. 2017. Economics of LED lighting, p. 81-99. In: D. Gupta (ed.). Light emitting diodes for agriculture - Smart lighting. Springer, Singapore.

Caldwell, C.R. and S.J. Britz. 2006. Effect of supplemental ultraviolet radiation on the carotenoid and chlorophyll composition of greenhouse-grown leaf lettuce (Lactuca sativa L.) cultivars. J. Food Compos. Anal. 19: 617-644.

Cataldo, D.A., M. Haroon, L.E. Schrader, and V.L. Youngs. 1975. Rapid colorimetric determination of nitrate in plant tissue by nitration of salicylic acid. Commun. Soil Sci. Plant Anal. 6:71-80.

Carvalho, S.D. and K.M. Folta. 2014. Environmentally modified organisms-Expanding genetic potential with light. Crit. Rev. Plant Sci. 33: 486-508.

Colonna, E., Y. Rouphael, G. Barbieri, and S. De Pascale. 2016. Nutritional quality of ten leafy vegetables harvested at two light intensities. Food Chem. 199:702-710.

Dougher, T.A.O. and B. Bugbee. 2004. Long-term blue light effects on the histology of lettuce and soybean leaves and stems. J. Amer. Soc. Hort. Sci. 129:467-472.

Escobar-Gutierrez, A., I. Burns, A. Lee, and R. Edmondson. 2002. Screening lettuce cultivars for low nitrate content during summer and winter production. J. Hort. Sci. Biotechnol. 77:232-237.

Folta, K.M. 2019. Breeding new varieties for controlled environments. Plant Biol. 21:6-12.

Gangolli, S.D., P.A. van den Brandt, V.J. Feron, C. Janzowsky, J.H. Koeman, G.J.A. Speijers, B. Spiegelhalder, R. Walker, and J.S. Wishnok. 1994. Nitrate, nitrite and N-nitroso compounds. Europ. J. Pharmacol. Environ. Toxicol. Pharmacol. 292:1-38.

Gazula, A., M.D. Kleinhenz, J.C. Scheerens, and P.P. Ling. 2007. Anthocyanin levels in nine lettuce (Lactuca sativa) cultivars: Influence of planting date and relations among analytic, instrumented, and visual assessments of color. HortScience 42:232-238.

Gent, M.P.N. 2014. Effect of daily light integral on composition of hydroponic lettuce. HortScience 49:173-179.

Johkan, M., K. Shoji, F. Goto, S. Hashida, and T. Yoshihara. 2010. Blue light-emitting diode light irradiation of seedlings improves seedling quality and growth after transplanting in red leaf lettuce. HortScience 45:1809-1814.

Khare, M. and K.N. Guruprasad. 1993. UV-B induced anthocyanin synthesis in maize regulated by FMN and inhibitors of FMN photoreactions. Plant Sci. 91:1-5.

Karvansara, P.R. and S.M. Razavi. 2019. Physiological and biochemical responses of sugar beet (Beta vulgaris L.) to ultraviolet-B radiation. PeerJ 7:e6790, doi: 10.7717/peerj.6790.

Kim, D.-E., X. Shang, A.D. Assefa, Y.-S. Keum, and R.K. Saini. 2018. Metabolite profiling of green, green/red, and red lettuce cultivars: Variation in health beneficial compounds and antioxidant potential. Food Res. Intl. 105:361370 .

Lee, J., R.W. Durst, and R.E. Wrolstad. 2005. Determination of total monomeric anthocyanin pigment content of fruit juices, beverages, natural colorants, and wines by the $\mathrm{pH}$ differential method: Collaborative study. J. AOAC Intl. 88:1269-1278.

Li, Q. and C. Kubota. 2009. Effects of supplemental light quality on growth and phytochemicals of baby leaf lettuce. Environ. Exp. Bot. 67:59-64.

Lichtenthaler, H.K. and C. Buschmann. 2001. Chlorophylls and carotenoids: Measurement and characterization by UV-VIS spectroscopy. In: R.E. Wrolstad (ed.). Current protocols in food analytical chemistry. Wiley, New York.

Lin, K.H., M.Y. Huang, W.D. Huang, M.H. Hsu, Z.W. Yang, and C.M. Yang. 2013. The effects of red, blue, and white light-emitting diodes on 
the growth, development, and edible quality of hydroponically grown lettuce (Lactuca sativa L. var. capitata). Scientia Hort. 150:86-91.

Llorach, R., A. Martínez-Sánchez, F.A. TomásBarberán, M.I. Gil, and F. Ferreres. 2008. Characterisation of polyphenols and antioxidant properties of five lettuce varieties and escarole. Food Chem. 108:1028-1038.

McCree, K.J. 1972. The action spectrum, absorptance and quantum yield of photosynthesis in crop plants. Agr. Meteorol. 9:191-216.

Mitchell, C.A. and F. Sheibani. 2020. LED advancements for plant factory artificial lighting, p. 167-184. In: T. Kozai, G. Niu, and M. Takagaki (eds.). Plant factory. 2nd ed. Academic Press, London, UK.

Mou, B.Q. 2005. Genetic variation of beta-carotene and lutein contents in lettuce. J. Amer. Soc. Hort. Sci. 130:870-876.

Mulabagal, V., M. Ngouajio, A. Nair, Y. Zhang, A.L. Gottumukkala, and M.G. Nair. 2010. In vitro evaluation of red and green lettuce ( $L a c$ tuca sativa) for functional food properties. J. Food Chem. 118:300-306.

Murchie, E.H. and K.K. Niyogi. 2011. Manipulation of photoprotection to improve plant photosynthesis. Plant Physiol. 155:86-92.

Nicole, C.C.S., F. Charalambous, S. Martinakos, S. van de Voort, Z. Li1, M. Verhoog, and M.P.C. Krijn. 2016. Lettuce growth and quality optimization in a plant factory. Acta Hort. 1134: 231-238.

Nicole, C.C.S., J. Mooren, A.T. Pereira Terra, D.H. Larsen, E.J. Woltering, L.F.M. Marcelis, J. Verdonk, R. Schouten, and F. Troost. 2019a. Effects of LED lighting recipes on postharvest quality of leafy vegetables grown in a vertical farm. Acta Hort. 1256:481-488.

Nicole, C.C.S., M.P.C. Krijn, and U. van Slooten 2019 b. Postharvest quality of leafy greens growing in a plant factory, p. 33-43. In: M Anpo, H. Fukuda, and T. Wada (eds.). Plant factory using artificial light, adapting to environmental disruption and clues to agricultural innovation. Elsevier, Amsterdam, The Netherlands.

Oh, M.M., E.E. Carey, and C.B. Rajashekar. 2009 Environmental stresses induce health-promoting phytochemicals in lettuce. Plant Physiol. Biochem. 47:578-583.

Ohashi-Kaneko, K., M. Takase, N. Kon, K. Fujiwara, and K. Kurata. 2007. Effect of light quality on growth and vegetable quality in leaf lettuce, spinach and komatsuna. Environ. Control Biol. 45:189-198.

Owen, W.G. and R.G. Lopez. 2015. End-ofproduction supplemental lighting with red and blue light-emitting diodes (LEDs) influences red pigmentation of four lettuce varieties. HortScience 50:676-684.

Paz, M., P.R. Fisher, and C. Gómez. 2019. Minimum light requirements for indoor gardening of lettuce. Urban Agr. Reg. Food Syst. 4:1-10.

Pérez-López, U., J. Miranda-Apodaca, A. MuñozRueda, and A. Mena-Petite. 2013. Lettuce production and antioxidant capacity are differentially modified by salt stress and light intensity under ambient and elevated $\mathrm{CO}_{2}$. J. Plant Physiol. 170:1517-1525.
Pérez-López, U., C. Pinzino, M.F. Quartacci, A.M. Ranieri, and C. Sgherri. 2014. Phenolic composition and related antioxidant properties in differently colored lettuces: A study by Electron Paramagnetic Resonance (EPR) kinetics. J. Agr. Food Chem. 62:12001-12007.

Pérez-López, U., C. Sgherri, J. Miranda-Apodaca, F. Micaelli, M. Lacuesta, A. Mena-Petite, M.F Quartacci, and A. Muñoz-Rueda. 2018. Concentration of phenolic compounds is increased in lettuce grown under high light intensity and elevated $\mathrm{CO}_{2}$. Plant Physiol. Biochem. 123: 233-241.

Rajabbeigi, E., I. Eichholz, N. Beesk, C. Ulrichs, L. Kroh, S. Rohn, and S. Huyskens-Keil. (2013). Interaction of drought stress and UV-B radiation-Impact on biomass production and flavonoid metabolism in lettuce (Lactuca sativa L.). J. Applied Bot. Food Quality 86:190-197.

Richards, J.T., N.C. Yorio, S.L. Edney, C.E Yunker, and G.W. Stutte. 2004. Evaluating growth characteristics and total anthocyanin content in three cultivars of red romaine-type lettuce (Lactuca sativa L.) in response to three lighting intensities. Proc. Plant Growth Regulat. Soc. Amer. 31:110-115.

Rodriguez-Saona, L.E. and R.E. Wrolstad. 2001 Anthocyanins: Extraction, isolation and purification of anthocyanins, p. F1.1.1-F1.1.11. In: R.E. Wrolstad (ed.). Current protocols in food analytical chemistry. John Wiley \& Sons, New York.

Ryder, E.J. 1999. Marketing economics and food safety, p. 164-171. In: E.J. Ryder (ed.). Lettuce endive and chicory. CABI Publ., New York.

Sager, J.C., W.O. Smith, J.L. Edwards, and K.L. Cyr. 1988. Photosynthetic efficiency and phytochrome photoequilibria determination using spectral data. Trans. Amer. Soc. Agr. Eng. 31:1882-1889.

Samuolienė, G., A. Urbonavičiūtè, P. Duchovskis, Z. Bliznikas, P. Vitta, and A. Žukauskas. 2009. Decrease in nitrate concentration in leafy vegetable under a solid-state illuminator. HortScience 44:1857-1860.

Samuoliené, G., R. Sirtautas, A. Brazaitytè, A Viršile, and P. Duchovskis. 2012. Supplementary red-LED lighting and the changes in phytochemical content of two baby leaf lettuce varieties during three seasons. J. Food Agr. Environ. 10:701-706.

Samuolienė, G., A. Brazaitytè, and V. Vaštakaite 2017. Light-emitting diodes (LEDs) for improved nutritional quality, p. 149-190. In: S.D. Gupta (ed.). Light emitting diodes for agriculture: Smart lighting. Springer Nature, Singapore.

Santamaria, P. 2006. Nitrate in vegetables: Toxicity, content, intake and EC regulation. J. Sci. Food Agr. 86:10-17.

Son, K.H. and M.M. Oh. 2013. Leaf shape, growth, and antioxidant phenolic compounds of two lettuce cultivars grown under various combinations of blue and red light-emitting diodes. HortScience 48:988-995.

Stagnari, F., A. Galieni, and M. Pisante. 2015. Shading and nitrogen management affect quality, safety and yield of greenhouse-grown leaf lettuce. Scientia Hort. 192:70-79.
Thakur, M., S. Bhattacharya, P.K. Khosla, and S. Puri. 2019. Improving production of plant secondary metabolites through biotic and abiotic elicitation. J. Appl. Res. Med. Aromat. Plants 12:1-12.

Tsormpatsidis, E., R.G.C. Henbest, F.J. Davis, N.H. Battey, P. Hadley, and A. Wagstaffe. 2008. UV irradiance as a major influence on growth, development and secondary products of commercial importance in Lollo Rosso lettuce 'Revolution' grown under polyethylene films. Environ. Exp. Bot. 63:232-239.

Viršile, A., A. Brazaityte, J. Jankauskienè, J. Miliauskienè, V. Vaštakaitè, I. Odminytè, A. Novičkovas, and G. Samuolienė. 2018. Preharvest LED lighting strategies for reduced nitrate contents in leafy vegetables. Zemdirbyste-Agr. 105:249-256.

Viršilè, A., A. Brazaitytè, V. Vaštakaitè-Kairienè, J. Miliauskiene, J. Jankauskienè, A. Novičkovas, K. Laužikè, and G. Samuolienè. 2020. The distinct impact of multi-color LED light on nitrate, amino acid, soluble sugar and organic acid contents in red and green leaf lettuce cultivated in controlled environment. Food Chem. 310:125799.

Voipio, I. and J. Autio. 1995. Responses of red-leaved lettuce to light intensity, UV-A radiation and root zone temperature. Acta Hort. 399:183-187.

Walker, R. 1990. Nitrates, nitrites and Nnitrosocompounds: A review of the occurrence in food and diet and the toxicological implications. Food Addit. Contam. 7:717-768

Wargent, J.J., J.P. Moore, A. Roland Ennos, and N.D. Paul. 2009. Ultraviolet radiation as a limiting factor in leaf expansion and development. Photochem. Photobiol. 85:279-286.

Woltering, E.J. and I.M. Witkowska. 2016. Effects of pre- and postharvest lighting on quality and shelf life of fresh-cut lettuce. Acta Hort. 1134: 357-365.

Yan, Z., D. He, G. Niu, Q. Zhou, and Y. Qu. 2019. Growth, nutritional quality, and energy use efficiency of hydroponic lettuce as influenced by daily light integrals exposed to white versus white plus red light-emitting diodes. HortScience 54:1737-1744.

Zhang, M., C.M. Whitman, and E.S. Runkle. 2019. Manipulating growth, color, and taste attributes of fresh cut lettuce by greenhouse supplemental lighting. Scientia Hort. 252:274-282.

Zheng, L. and M.-C. Van Labeke. 2017. Long-term effects of red- and blue-light emitting diodes on leaf anatomy and photosynthetic efficiency of three ornamental pot plants. Front. Plant Sci. $8: 1-12$.

Zhou, W.L., W.K. Liu, and Q.C. Yang. 2012. Quality changes in hydroponic lettuce grown under pre-harvest short-duration continuous light of different intensities. J. Hort. Sci. Biotechnol. 87:429-434.

Žukauskas, A., Z. Bliznikas, K. Breivè, A. Novičkovas, G. Samuolienè, A. Urbonavičiūte, A. Brazaitytè, J. Jankauskienè, and P. Duchovskis. 2011. Effect of supplementary pre-harvest LED lighting on the antioxidant properties of lettuce cultivars. Acta Hort. 907:87-90. 